\title{
Drought Periods Identification in Ecuador between 2001 and 2018 Using SPEI and MODIS Data ${ }^{\dagger}$
}

\author{
César Sáenz ${ }^{1,2, * \mathbb{D}}$, Javier Litago ${ }^{1}$, Klaus Wiese ${ }^{3,4}$, Laura Recuero ${ }^{2}$, Victor Cicuéndez ${ }^{1} \mathbb{D}$ and \\ Alicia Palacios-Orueta 2,5
}

1 Departamento de Economía Agraria, Estadística y Gestión de Empresas, ETSIAAB, Universidad Politécnica de Madrid (UPM), Avda. Complutense 3, 28040 Madrid, Spain; javier.litago@upm.es (J.L.); victor.cicuendez.lopezocana@alumnos.upm.es (V.C.)

2 Centro de Estudios e Investigación para la Gestión de Riesgos Agrarios y Medioambientales (CEIGRAM), Universidad Politécnica de Madrid (UPM), C/Senda del Rey 13 Campus Sur de prácticas de la ETSIAAB, 28040 Madrid, Spain; laura.recuero@upm.es (L.R.); alicia.palacios@upm.es (A.P.-O.)

3 Escuela de Biología, Universidad Nacional Autónoma de Honduras, Tegucigalpa 11101, Honduras; klauswiese@hotmail.com

4 Programa de Ingeniería y Gestión del Medio Natural, Escuela Técnica Superior de Ingeniería de Montes, Forestal Y del Medio Natural, Universidad Politécnica de Madrid, 28040 Madrid, Spain

5 Departamento de Ingeniería Agroforestal, ETSIAAB, Universidad Politécnica de Madrid (UPM), Avda. Complutense 3, 28040 Madrid, Spain

* Correspondence: cesar.saenzf@alumnos.upm.es

+ Presented at the 13th EFITA International Conference, Online, 25-26 May 2021.

check for updates

Citation: Sáenz, C.; Litago, J.; Wiese,

K.; Recuero, L.; Cicuéndez, V.;

Palacios-Orueta, A. Drought Periods Identification in Ecuador between 2001 and 2018 Using SPEI and MODIS Data. Eng. Proc. 2021, 9, 24. https: / /doi.org/10.3390/engproc 2021009024

Academic Editors: Dimitrios Kateris and Maria Lampridi

Published: 25 November 2021

Publisher's Note: MDPI stays neutral with regard to jurisdictional claims in published maps and institutional affiliations.

Copyright: (c) 2021 by the authors. Licensee MDPI, Basel, Switzerland. This article is an open access article distributed under the terms and conditions of the Creative Commons Attribution (CC BY) license (https:/ / creativecommons.org/licenses/by/ $4.0 /)$.

\begin{abstract}
Drought is a natural phenomenon in which the precipitation amount is below normal in a specific region over a long period. The main objective of this study is to identify periods of drought in Ecuador between 2001 and 2018 using the Standardized Precipitation Evapotranspiration Index (SPEI) and the Normalized Difference Water Index (NDWI) derived from MODIS data. Firstly, the SPEI at a six-month scale and the Runs theory were used to identify periods of drought. Secondly, the NDWI from MOD09A1 MODIS product was used to identify the areas affected by drought.
\end{abstract}

Keywords: drought; SPEI; NDWI; remote sensing; Ecuador

\section{Introduction}

More frequent and intense drought events during the last few years are a clear consequence of climate change worldwide. Drought is defined as a natural phenomenon in which rainfall values are below normal in a specific region over a prolonged period [1]. However, drought is a complex phenomenon and presents different ways with diverse features [2]. The American Meteorological Society classifies it into four categories: meteorological or climatological drought, hydrological drought, agricultural drought and socioeconomic drought [3].

The scientific community has developed several indices in order to assess this complex phenomenon using, two main different methods [4]: (a) indices developed with a traditional meteorological method, taking into account meteorological variables, such as the Standardized Precipitation Evapotranspiration Index (SPEI) [5] and (b) indices computed using multispectral information from remote sensors, such as the Normalized Difference Water Index (NDWI) that evaluates the water content in vegetation and soils [6]. This index has been widely used for drought monitoring, especially when using satellite imagery offering a frequent and continuous spatial observation, even in areas where access is difficult. Resolution Imaging Spectroradiometer (MODIS), available since the beginning of the 2000s, has been widely used for drought monitoring at national scales [7] being especially interesting when analyzing long time series.

The main objective of this study is to develop a methodology to assess drought periods in Ecuador between 2001 and 2018 using the SPEI and NDWI indices. 


\section{Materials and Methods}

\subsection{Study Region}

Ecuador is located between latitudes $1^{\circ} 28^{\prime} \mathrm{N}-5^{\circ} 01^{\prime} \mathrm{S}$ and longitudes $75^{\circ} 11^{\prime} \mathrm{W}-81^{\circ} 01^{\prime}$ $\mathrm{W}$ and it is bordered to the west by the Pacific Ocean. The average temperature in Ecuador varies between regions, fluctuating between $20^{\circ} \mathrm{C}$ and $26^{\circ} \mathrm{C}$. The total annual precipitation varies with respect to temporal and spatial distribution from $250 \mathrm{~mm}$ on the Coast to $4000 \mathrm{~mm}$ in the Amazon. According to the Köppen classification, Ecuador has a humid tropical climate (Af), without defined climatic seasons, although two well-marked periods: dry season (June-November) and rainy season (December-May). This research is focused on continental Ecuador, which is divided into three regions: Coast, Andean and Amazon. This area expands across $256,370 \mathrm{~km}^{2}$ with a population of approximately 17.6 million people.

\subsection{Data Source and Processing Meteorological and MODIS Data}

The Climate Research Unit (CRU) Time-Series (TS), version 4.03 of high-resolution gridded climate dataset with a spatial resolution of 0.5 degrees [8], was used to obtain monthly temperature and precipitation observations for the period 2001-2018.

The MOD09A1 version 6 product from MODIS sensor [9] was used to calculate NDWI spectral index. This product consists of 8 days temporal composites with a $500 \mathrm{~m}$ spatial resolution containing reflectance values at seven spectral bands: $620-670 \mathrm{~nm}$ (Red), 841-876 nm (Nir), 459-479 nm (Blue), 545-565 nm (Green), 1230-1250 nm (SWIR 1 ), 1628$1652 \mathrm{~nm}\left(\mathrm{SWIR}_{2}\right), 2105-2155 \mathrm{~nm}\left(\mathrm{SWIR}_{3}\right)$. To cover all continental Ecuador, it was necessary to download and process information from 4 tiles (h09v08, h09v09, h10v08, h10v09). The data were downloaded from the NASA website (https:/ / lpdaac.usgs.gov, accessed on 20 April 2021) and for the period 2001-2018.

\subsection{Research Methods}

\subsubsection{Calculation of the SPEI}

The SPEI proposed by V. Serrano in 2010, is an index focused on detecting drought from climatic data calculated from the difference in precipitation and potential evapotranspiration for different spatial and temporal scales (1 to 48 months). In this study, a six-month scale was used. The SPEI values range from -2 to 2 and the categories are: extremely wet $(\geq 2)$, severely wet (1.50 to 1.99$)$, moderately wet (1 to 1.49$)$, normal $(-0.99$ to 0.99$)$, moderate drought $(-1$ to -1.49$)$, severe drought $(-1.50$ to -1.99$)$ and extreme drought $(\leq-2)$.

\subsubsection{Calculation of the NDWI}

The NDWI proposed by Gao in 1996 uses the bands of NIR and SWIR 1 to identify moisture (Equation (1)) [6]. The range of the NDWI is from -1 to 1 . When the value is closer to 1 , vegetation is considered to contain high moisture, and if it approaches 0 , it is associated with surfaces without the presence of vegetation or bodies of water [10].

$$
\mathrm{NDWI}=\left(\mathrm{NIR}-\mathrm{SWIR}_{3}\right) /\left(\mathrm{NIR}+\mathrm{SWIR}_{3}\right),
$$

The ranges we use for the different NDWI categories were: very high moisture $(>0.7)$, high moisture ( 0.61 to 0.7$)$, moderate moisture ( 0.51 to 0.6$)$, low moisture ( 0.41 to 0.5$)$, weak moisture $(0.31$ to 0.4$)$, moderate drought $(0.21$ to 0.3$)$, strong drought (0.01 to 0.2$)$ and very strong drought $(\leq 0)$. 


\subsection{Methodology}

\subsubsection{Runs Theory}

Once the six-month SPEI was calculated, it was analyzed using the Runs theory [11] that allows finding the duration, severity, intensity and identifying the dates of the drought periods.

\subsubsection{NDWI Images}

To map and calculate the area affected by drought, the dry period was identified with the Runs theory. The pixels are classified with the proposed NDWI values and those that are less than or equal to 0.3 are considered as affected surfaces.

\section{Results}

The years that were identified as dry periods were 2005 and 2018. Although 2005 was the year most affected at national level, the Coastal region had the highest severity value of -1.43 and a duration of 10 months, following the Andean and Amazon region in Table 1.

Table 1. The most important dry periods between 2001 to 2018 of continental Ecuador regions.

\begin{tabular}{ccccccc}
\hline Region & \multicolumn{2}{c}{ Coast } & \multicolumn{2}{c}{ Andean } & \multicolumn{2}{c}{ Amazon } \\
\hline Year & $\mathbf{2 0 0 5}$ & $\mathbf{2 0 1 8}$ & $\mathbf{2 0 0 5}$ & $\mathbf{2 0 1 8}$ & $\mathbf{2 0 0 5}$ & $\mathbf{2 0 1 8}$ \\
\hline Duration & 10 & 6 & 13 & 6 & 6 & 6 \\
Severity & -14.25 & -6.79 & -17.80 & -7.16 & -7.57 & -7.35 \\
Intensity & -1.43 & -1.13 & -1.37 & -1.19 & -1.26 & -1.23 \\
Date & January- & April- & February- & April- & May- & March- \\
& October & September & February & September & October & August \\
\hline
\end{tabular}

In Figure 1, the drought period of 2005 using the NDWI and pixels with values less than 0.3 were classified as affected by drought and the most affected month was October, which affected $32.36 \%$ of the total surface of continental Ecuador.

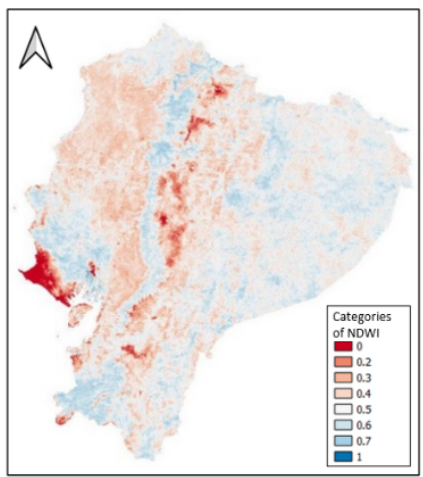

(a)

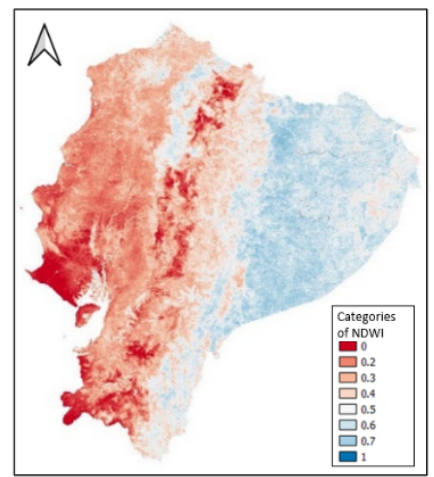

(b)

Figure 1. Surface of the month least and the most affected by drought in 2005: (a) May 4.74\%; (b) October $32.36 \%$.

\section{Discussion and Conclusions}

The combination of SPEI on a six-month scale and NDWI from MODIS provided relevant information tools for the identification, assessment and monitoring of dry periods and estimation of the affected surface. It was possible to identify the dates of duration of the dry periods and their levels of affectation based on the SPEI on a six-month basis, and the surface affected based on the NDWI information.

The year 2005 was the most affected by drought in all regions of Ecuador, followed by 2018, which also has high intensity values, but with a shorter duration than 2005. The year 2005 has been considered the driest year in the last 100 years in the southwestern part of 
the Amazon [12]. It was important to identify the month (October 2005) and the region most affected (Coast region) by this natural threat to be able to take preventive measures in the future, knowing that the sector of first necessity is the agricultural sector.

Author Contributions: Conceptualization, C.S. and J.L.; methodology, C.S. and J.L.; software, K.W. and L.R.; validation, K.W. and L.R.; formal analysis, C.S., J.L. and A.P.-O.; investigation, C.S., J.L., A.P.-O., V.C., L.R. and K.W.; resources, C.S., L.R. and V.C.; data curation, C.S. and L.R.; writingoriginal draft preparation, C.S., V.C. and L.R.; writing-review and editing, C.S., V.C., J.L. and A.P.-O. All authors have read and agreed to the published version of the manuscript.

Funding: César Sáenz was supported by a predoctoral scholarship awarded by the Community of Madrid (No. IND2020/AMB-17747).

Data Availability Statement: Publicly available datasets were analyzed in this study. This data can be found here: https:/ /lpdaac.usgs.gov (accessed on 20 April 2021).

Acknowledgments: The authors would like to thank NASA for providing MODIS data. We are especially grateful to the anonymous reviewers and editors for reviewing our manuscript and for offering feedback.

Conflicts of Interest: The authors declare no conflict of interest.

\section{References}

1. Van Loon, A.F.; Laaha, G. Hydrological drought severity explained by climate and catchment characteristics. J. Hydrol. 2015, 526, 3-14. [CrossRef]

2. West, H.; Quinn, N.; Horswell, M. Remote sensing for drought monitoring \& impact assessment: Progress, past challenges and future opportunities. Remote Sens. Environ. 2019, 232, 111291. [CrossRef]

3. Wilhite, D.A.; Glantz, M.H. Understanding: The Drought Phenomenon: The Role of Definitions. Water Int. 1985, 10, 111-120. [CrossRef]

4. Du, L.; Tian, Q.; Yu, T.; Meng, Q.; Jancso, T.; Udvardy, P.; Huang, Y. A comprehensive drought monitoring method integrating MODIS and TRMM data. Int. J. Appl. Earth Obs. Geoinf. 2013, 23, 245-253. [CrossRef]

5. Vicente-Serrano, S.M.; Beguería, S.; López-Moreno, J.I. A multiscalar drought index sensitive to global warming: The standardized precipitation evapotranspiration index. J. Clim. 2010, 23, 1696-1718. [CrossRef]

6. Gao, B. NDWI-A Normalized Difference Water Index for Remote Sensing of Vegetation Liquid Water From Space. Remote Sens. Environ. 1996, 58, 257-266. [CrossRef]

7. Xie, F.; Fan, H. Deriving drought indices from MODIS vegetation indices (NDVI/EVI) and Land Surface Temperature (LST): Is data reconstruction necessary? Int. J. Appl. Earth Obs. Geoinf. 2021, 101, 102352. [CrossRef]

8. Harris, I.; Osborn, T.J.; Jones, P.; Lister, D. Version 4 of the CRU TS monthly high-resolution gridded multivariate climate dataset. Sci Data 2020, 7, 109. [CrossRef] [PubMed]

9. Vermote, E. MOD09A1 MODIS/Terra Surface Reflectance 8-Day L3 Global 500m SIN Grid V006. 2015. Distributed by NASA EOSDIS Land Processes DAAC. Available online: https:/ / doi.org/10.5067/MODIS/MOD09A1.006 (accessed on 20 April 2021).

10. Gulácsi, A.; Kovács, F. Drought monitoring with spectral indices calculated from modis satellite images in hungary. J. Environ. Geog. 2015, 8, 11-20. [CrossRef]

11. Yevjevich, V. An Objective Approach to Definitions and Investigations of Continental Hydrologic Drought; Hydrology; Paper No. 23; Colorado State University: Fort Collins, CO, USA, 1967.

12. Marengo, J.A.; Nobre, C.A.; Tomasella, J.; Oyama, M.D.; Sampaio de Oliveira, G.; de Oliveira, R.; Camargo, H.; Alves, L.M.; Brown, I.F. The Drought of Amazonia in 2005. J. Clim. 2008, 21, 495-516. [CrossRef] 